\title{
Soil chemical attributes of a Dystroferric Red Latosol (Oxisol) treated with an alkaline effluent from a pharmaceutical industry
}

\section{Atributos químicos de um Latossolo Vermelho distroférrico após aplicação de efluente alcalino da indústria farmacêutica}

\author{
Michel Esper Neto; ; Marcelo Augusto Batista ${ }^{2 *}$; Tadeu Takeyoshi Inoue ${ }^{2}$; \\ Altair Bertonha ${ }^{2}$; Antonio Carlos Saraiva da Costa $^{2}$
}

\begin{abstract}
Effluents from different industrial supply conglomerates are often discarded in the environment without proper treatment. The concern for an economically viable industrial production line, which is both environmentally sound and socially acceptable, is increasing. Some of these effluents are alkaline in nature and may be used as an alternative to chemical conditioners for acidic soils in agricultural systems. This research aimed to evaluate changes in the chemical attributes of a Dystroferric Red Latosol (Oxisol) after application of an effluent from a pharmaceutical industry. The experiment was conducted in a greenhouse using PVC tubes of $1-\mathrm{m}$ length and a $0.2-\mathrm{m}$ diameter filled with soil and different doses of the effluent. After 3 days, $100 \mathrm{~mm}$ of water was applied to each treatment. The PVC tubes were incubated for 30 days; thereafter, the tubes disassembled, and soil chemical analysis were made at different soil depths: $0-0.2,0.2-0.4,0.4-0.6,0.6-0.8$, and $0.8-1.0 \mathrm{~m}$. The effluent applications significantly altered the soil elements in the $0-0.2$ m layer, increasing the concentrations of $\mathrm{K}^{+}, \mathrm{P} \mathrm{Mn}^{2+}$, $\mathrm{Na}^{+}, \mathrm{Cu}^{2+}, \mathrm{H}^{+}, \mathrm{Ca}^{2+}, \mathrm{Al}^{3+}$ and the soil $\mathrm{pH}$. In the subsurface layers, the concentration of the elements $\mathrm{Zn}^{2+}, \mathrm{Cu}^{2+}, \mathrm{K}^{+}$, and $\mathrm{Na}^{+}$also changed significantly. In general, the application of pharmaceutical industry residue improved soil chemical attributes.
\end{abstract}

Key words: Conditioner. Residue. Na.

\section{Resumo}

Os efluentes das diversas cadeias produtivas industriais são muitas vezes descartados no ambiente sem tratamento adequado. A preocupação por uma linha de produção industrial economicamente viável, ambientalmente correta e socialmente aceita é cada vez mais preconizada. Alguns desses efluentes apresentam caráter alcalino, e podem ser utilizados como condicionadores químicos de solos ácidos, em sistemas agrícolas. Objetivou-se com a realização do presente trabalho, avaliar alterações químicas de um LATOSSOLO VERMELHO distroférrico, após aplicação de efluente da indústria farmacêutica. O experimento foi realizado em casa de vegetação e conduzido em tubos de PVC de $1 \mathrm{~m}$ de comprimento e $0,2 \mathrm{~m}$ de diâmetro. Nos tubos, preenchidos com solo, foram aplicadas diferentes doses do efluente. Após 3 dias, $100 \mathrm{~mm}$ de água foi aplicado sobre cada tratamento. As colunas foram incubadas por 30 dias, posteriormente desmontadas e feitas análises químicas nas diferentes profundidades: $0-0,2 ; 0,2$ 0,$4 ; 0,4-0,6 ; 0,6-0,8$ e $0,8-1,0 \mathrm{~m}$. As aplicações do efluente fizeram com que alguns elementos do solo aumentassem significativamente sua concentração, principalmente na camada de 0-0,2 m entre eles

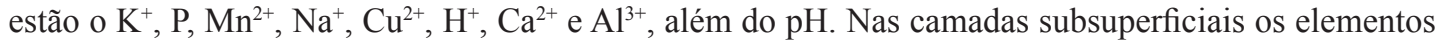
$\mathrm{Zn}^{2+}, \mathrm{K}^{+}, \mathrm{Cu}^{2+} \mathrm{e} \mathrm{Na}{ }^{+}$sofreram alterações significativas. A aplicação do resíduo da indústria farmacêutica melhorou as características químicas do solo.

Palavras-chave: Condicionador. Resíduo. Na.

\footnotetext{
${ }^{1}$ Discente do Curso de Mestrado no Programa de Pós-Graduação em Agronomia, Universidade Estadual de Maringá, UEM, Maringá, PR, Brasil. Bolsista CNPq. E-mail: michelesper14@gmail.com

${ }^{2}$ Profs. Drs., Departamento de Agronomia, UEM, Maringá, PR, Brasil. E-mail: mabatista@uem.br; ttinoue@uem.br; abertonha@ uem.br; acscosta@uem.br

* Author for correspondence
} 


\section{Introduction}

Soil and water contamination from effluents generated by industries have become a subject of worldwide relevance, particularly due to the improper disposal of these wastes, which is often performed in a random manner. Societal pressure and concerns of the industry have resulted in the search for more sustainable forms of production with minimum waste generation (NASCIMENTO, 2012).

Industrial pharmaceutical complexes are constantly developing worldwide. Brazil is among the ten largest markets for drugs and medicines, possessing 540 registered establishments and generating 28 billion reais per year in drug production for human consumption in efforts to prevent and fight diseases (YUNES et al., 2001).

To provide the final product to the costumer, these drugs undergo different chemical processes during manufacturing, during which many substances are synthesized and thereafter become unserviceable. Chemical by-products of production can have the potential to pollute both biotic and abiotic components of the environment (CRESTANA; SILVA, 2011).

Soil and water contamination can occur by improper disposal of these industrial wastes and human and animal excretion or by the disposal of medicines in household garbage and sewage.

In some processes of the pharmaceutical industry, generated wastes may have specific chemical and physical properties that would allow them to be used as soil conditioners to improve water and nutrient availability (ALBUQUERQUE et al., 2011). The use of residues as an alternative treatment for soil acidity and soil fertility correction can be an interesting proposal from social, economic, and environmental perspectives because the application costs of these residues is smaller than the fertilizer and lime typically used, and this application is a proper disposal technology (PÉRTILE et al., 2012). However, the great majority of wastes that might be used as soil conditioners are discarded in landfills and do not have adequate pretreatment before being exposed to the environment, thus becoming a potential risk to living organisms.

In the literature, there are several studies showing the use of residues as alternative sources of nutrients and soil conditioners in agriculture; however, before use, these wastes should be carefully analyzed to avoid environmental and economic problems because when disposed of in an improper way, they can cause contamination, mainly from heavy metals and infectious organisms (ALMEIDA et al., 2008).

Almeida et al. (2008) showed that applications of alkaline wastes from the pulp and paper industry promoted an improvement in soil fertility, especially in relation to acidity correction. Krob et al. (2011), worked with the application of urban wastes to soil and observed increasing $\mathrm{pH}$, organic matter $\mathrm{P}, \mathrm{C}$, $\mathrm{Ca}^{2+}$, and $\mathrm{Mg}^{2+}$, as well as decreasing $\mathrm{Al}^{3+}$ contents. Mantovani et al. (2005) found similar results for $\mathrm{pH}, \mathrm{P}, \mathrm{Ca}^{2+}$, and $\mathrm{Mg}^{2+}$.

However, industrial wastes may also contain chemical and biological compounds that may adversely affect plant production via excess alkalinity or acidity, presence of highly infectious microorganisms, and sodium content (SILVA et al., 2010). Such characteristics might limit the dosing to be applied or require pretreatment to eliminate or attenuate the action of possible soil pollutants components. Thus, the aim of this research was to evaluate the changes in the chemical attributes of Dystroferric Red Latosol (Oxisol) after application of different doses of an alkaline effluent from the pharmaceutical industry.

\section{Material and Methods}

The experiment was carried out in a greenhouse with controlled conditions in the Irrigation Training Center (CTI) of the Agronomy Department at Maringá State University (UEM), which is located in Maringá-PR. The soil used in the experiment, 
collected at a depth of $0-0.3 \mathrm{~m}$, is classified as a Dystroferric Red Oxisol (EMBRAPA, 2013). The soil was air dried, sieved (sieve $\mathrm{n}^{\circ} 10$ or $2 \mathrm{~mm}$ ), air dried again, and then analyzed for chemical and particle size attributes according to the methodologies described in EMBRAPA (1997) (Table 1).

Table 1. Chemical attributes and particle size analysis of the Dystroferric Red Latosol (Oxisol).

\begin{tabular}{|c|c|c|c|c|c|c|c|c|c|}
\hline pH H,O & $\mathbf{H}^{+}$ & $\mathbf{A l}^{3+}$ & $\mathrm{Ca}^{2+}$ & $\mathbf{M g}^{2+}$ & $\mathbf{K}^{+}$ & $\mathbf{N a}^{+}$ & $\mathbf{P}$ & $\mathbf{C}$ & \\
\hline \multirow[b]{2}{*}{5.2} & \multirow[b]{2}{*}{3.77} & \multirow[b]{2}{*}{0.2} & \multicolumn{3}{|c|}{$\mathrm{cmol} \mathrm{dm}^{-3}$} & \multicolumn{4}{|c|}{$\mathrm{mg} \mathrm{dm}^{-3} \mathrm{~g} \mathrm{dm}^{-3}$} \\
\hline & & & 1.61 & $0 .{ }^{c} 8$ & 0.08 & 3.1 & 1.6 & \multicolumn{2}{|l|}{4.61} \\
\hline SB & CEC & $\mathrm{V}$ & $\mathbf{C u}$ & $\mathrm{Zn}$ & $\mathrm{Fe}$ & Mn & Sand & Silt & Clay \\
\hline \multicolumn{2}{|c|}{$\mathrm{cmol}_{\mathrm{c}} \mathrm{dm}^{-3}$} & $\%$ & \multicolumn{4}{|c|}{$\mathrm{mg} \mathrm{dm}^{-3}$} & \multicolumn{3}{|c|}{$\mathrm{g} \mathrm{kg}^{-1}$} \\
\hline 2.37 & 6.34 & 37 & $4 . \overline{3}$ & 0.7 & 48 & 10 & 90 & 80 & 830 \\
\hline
\end{tabular}

$\mathrm{Ca}, \mathrm{Mg}$, and $\mathrm{Al}$ contents were extracted with $\mathrm{KCl} 1 \mathrm{~mol} \mathrm{~L}^{-1} ; \mathrm{P}, \mathrm{K}, \mathrm{Na}, \mathrm{Fe}, \mathrm{Zn}, \mathrm{Mn}$, and Cu contents were extracted with Mehlich-1; $\mathrm{H}+\mathrm{Al}$ was extracted with the SMP method, and; total C content was determined using the Walkey \& Black method.

The liquid effluent used was collected in February 2012 directly from the deposit boxes located at the rear of a pharmaceutical industry located in Arapongas-PR. Wastewater characterization was performed at Maringá State University for the following characteristics: Chemical Oxygen Demand (COD) in the condensate using the open reflux method; Biochemical Oxygen Demand (BOD) using the Winkler method; total solids (TS); $\mathrm{pH}$; organic matter content using the Walkley-Black method; total nitrogen using the micro-Kjeldahl method; available phosphorus using the colorimetric method; and available potassium and sodium using flame photometry (RICHARDS, 2012).

The experiment used a completely randomized design with 5 treatments and 4 repetitions. The air dried fine earth-ADFE was used to fill up the PVC tubes that were $1 \mathrm{~m}$ long (split into 5 segments of $0.20 \mathrm{~m}$ ) with a $0.20 \mathrm{~m}$ diameter. Final soil density was $1100 \mathrm{~kg} \mathrm{~m}^{-3}$, and each tube had $34.6 \mathrm{~kg} \pm 0.1$ of ADFE. After filling the tubes, different volumes of liquid effluents were applied corresponding to the following doses: $0 ; 26.3 ; 52.6 ; 78.9$ and $105.2 \mathrm{~m}^{3}$ $\mathrm{ha}^{-1}$. Three days after application, a rainfall of 100 $\mathrm{mm}$ was simulated to percolate the soluble contents of the effluent to different depths of the PVC tubes. Thirty days after the rainfall simulation, disturbed soil samples were collected from the middle portion of each $0.20 \mathrm{~m}$ segment at the following depths: $0.10 ; 0.30 ; 0.50 ; 0.70$ and $0.90 \mathrm{~m}$. The samples were tested for $\mathrm{pH}$ in $\mathrm{H}_{2} \mathrm{O}, \mathrm{H}^{+}+\mathrm{Al}^{3+}, \mathrm{Ca}^{2+}, \mathrm{Mg}^{2+}, \mathrm{K}^{+}, \mathrm{Na}^{+}$,

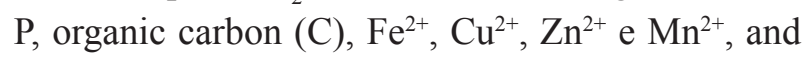
$\mathrm{Ca}: \mathrm{Mg}$ ratio.

The $\mathrm{H}^{+}$concentration values were obtained by subtracting the $\mathrm{Al}^{3+}$ content from the $\mathrm{H}^{+}+\mathrm{Al}^{3+}$ content, which was determined using the $\mathrm{pH}$ SMP method. The extraction of $\mathrm{P}, \mathrm{K}^{+}, \mathrm{Na}^{+}, \mathrm{Fe}^{3+}, \mathrm{Cu}^{2+}, \mathrm{Zn}^{2+}$, and $\mathrm{Mn}^{2+}$ was performed using Mehlich-1 acid solution (0.05 $\mathrm{mol} \mathrm{L}^{-1} \mathrm{HCl}$ and $\left.0.0125 \mathrm{~mol} \mathrm{~L}^{-1} \mathrm{H}_{2} \mathrm{SO}_{4}\right)$.

Available $\mathrm{Ca}^{2+}, \mathrm{Mg}^{2+}$ and $\mathrm{Al}^{3+}$ were extracted with $1 \mathrm{~mol} \mathrm{~L}^{-1} \mathrm{KCl}$. Available $\mathrm{P}$ was determined using the molybdate blue method and was measured with a spectrophotometer; $\mathrm{K}^{+}$and $\mathrm{Na}^{+}$ were measured using flame photometry. $\mathrm{Ca}^{2+}, \mathrm{Mg}^{2+}$, $\mathrm{Fe}^{3+}, \mathrm{Cu}^{2+}, \mathrm{Zn}^{2+}$ and $\mathrm{Mn}^{2+}$ were determined using an atomic absorption spectrophotometer, and $\mathrm{Al}^{3+}$ was measured using acid-base titration with $\mathrm{NaOH}$ $0.0125 \mathrm{~mol} \mathrm{~L}^{-1}$. Total $\mathrm{C}$ was determined using the Walkley \& Black method of oxidation of $\mathrm{K}_{2} \mathrm{Cr}_{4} \mathrm{O}_{7}$ in concentrated $\mathrm{H}_{2} \mathrm{SO}_{4}$ and titration with $0.25 \mathrm{~mol} \mathrm{~L}^{-1}$ $\mathrm{FeSO}_{4}$ (EMBRAPA, 1997).

The data collected were analyzed for normality using the Shapiro-Wilk test and, when necessary, 
were transformed prior to analysis of variance using the F test $(p<0.05)$. The quantitative factors (effluent doses) were subjected to regression analysis on each soil segment (ZIMMERMANN, 2014).

\section{Results and Discussion}

$\mathrm{pH}$ in $\mathrm{H}_{2} \mathrm{O}, \mathrm{H}^{+}, \mathrm{Al}^{3+}$ and $\mathrm{Na}^{+}$values

The $\mathrm{pH}$ values in $\mathrm{H}_{2} \mathrm{O}$ increased with the doses of applied effluent, and this behavior was statistically significant $(p<0.05)$ and positive only at a $0-0.2 \mathrm{~m}$ depth (Figure 1A). Increases in $\mathrm{pH}$ were approximately 0.02 units per cubic meter of applied liquid effluent, with 7.55 being the largest observed $\mathrm{pH}$ value. This behavior in the surface layer may have occurred because the $\mathrm{pH}$ of the effluent is higher (7.48) than the $\mathrm{pH}$ of the soil (5.2). The effluent also contains organic compounds and exchangeable cations of alkaline reactions, such as $\mathrm{K}^{+}$and $\mathrm{Na}^{+}$.

Figure 1. The $\mathrm{pH}$ in $\mathrm{H}_{2} \mathrm{O}$ and $\mathrm{H}^{+}, \mathrm{Al}^{3+}, \mathrm{Na}^{+}$contents at different depths of a Dystroferric Red Latosol (Oxisol) with different doses of the pharmaceutical industry effluent applied.
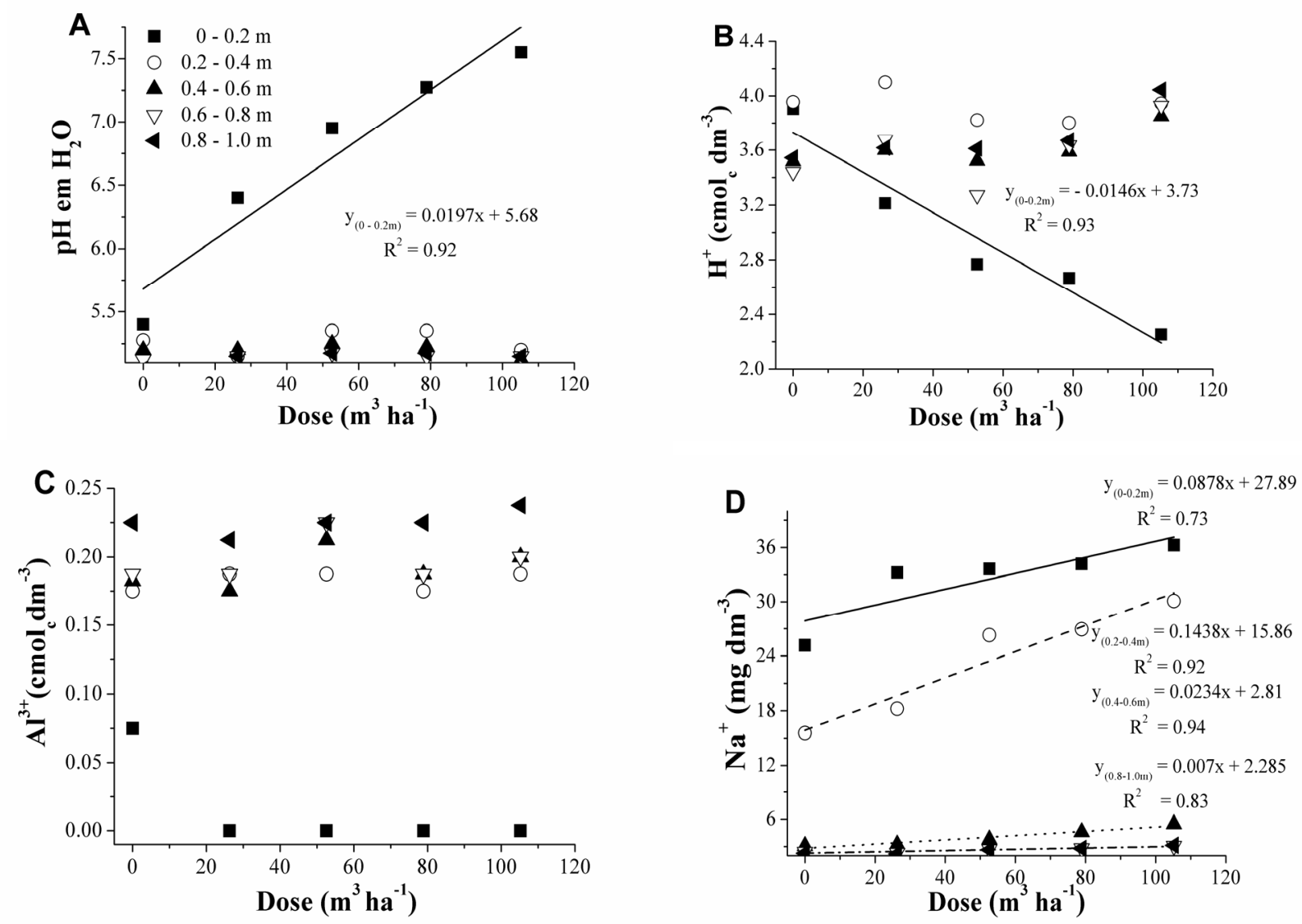

Medeiros et al. (2013) also observed increases in soil $\mathrm{pH}$ in the surface layers using liquid effluent. This result was explained by the presence of $\mathrm{NaOH}$ and $\mathrm{Ca}(\mathrm{OH})_{2}$ and the ability of organic matter to raise the $\mathrm{pH}$ via decarboxylation reactions of

organic anions, thus consuming $\mathrm{H}^{+}$and releasing $\mathrm{CO}_{2}$. The corrective effects of traditionally utilized sources of soil acidity (e.g., agricultural lime) have low vertical movement capabilities, especially in no-tillage systems where there is no incorporation 
of the amendment (SORATTO; CRUSCIOL, 2008). Soil $\mathrm{pH}$ influences the availability of nutrients and toxic elements, as well as soil microbiological activity (MOREIRA; SIQUEIRA, 2006). Although the effect of $\mathrm{pH}$ change was observed only at the 0-0.2 $\mathrm{m}$ depth, this is the portion of soil where the largest volumes of plant roots (e.g., 70 to $80 \%$ for soybeans) grow under normal crop conditions (GREGORY, 1992), showing that alkaline residues may be beneficial to plant development and can change the $\mathrm{pH}$ in relevant soil layers.
$\mathrm{H}^{+}$values followed an opposite trend to that observed in regards to soil $\mathrm{pH}$. With increasing doses of the effluent, a reduction of $\mathrm{H}^{+}$levels was observed (Figure 1B). This behavior was observed only in the $0-0.2 \mathrm{~m}$ depth, similar to soil $\mathrm{pH}$, with no significant difference $(\mathrm{p}>0.05)$ at other depths. As the effluent has alkaline $\mathrm{pH}$ (Table 2), the $\mathrm{OH}^{-}$neutralizes the $\mathrm{H}^{+}$, and its excess resulted in increased pH (ALBUQUERQUE et al., 2011).

Table 2. Chemical analysis of the raw liquid alkaline effluent used in the experiment.

\begin{tabular}{lc}
\hline Chemical attributes & Sample gross values \\
\hline COD $\left(\mathrm{mg} \mathrm{L}^{-1} \mathrm{O}_{2}\right)$ & 200000 \\
$\mathrm{BOD}\left(\mathrm{mg} \mathrm{L}^{-1} \mathrm{O}_{2}\right)$ & 92500 \\
Organic matter $(\%)$ & 2.81 \\
Total nitrogen $\left(\mathrm{mg} \mathrm{L}^{-1}\right)$ & 13265 \\
Total phosphorus $\left(\mathrm{mg} \mathrm{L}^{-1}\right)$ & 1554 \\
Total potassium $\left(\mathrm{mg} \mathrm{L}^{-1}\right)$ & 1.015 \\
Total solids & 4.040 \\
Total carbon $(\%)$ & 1.56 \\
pH & 7.48 \\
\hline
\end{tabular}

COD - Chemical Oxygen Demand; BOD - Biochemical Oxygen Demand.

The $\mathrm{Al}^{3+}$ concentration values did not change significantly $(\mathrm{p}>0.05)$ with increasing effluent doses (Figure 1C). Although average levels of $\mathrm{Al}^{3+}$ in the soil after application of the treatments are considered nontoxic $\left(\mathrm{Al}^{3+}<0.10 \mathrm{cmol}_{\mathrm{c}} \mathrm{dm}^{-3}\right)$ to plant roots in the top layer, the $\mathrm{Al}^{+3}$ levels approached zero. This result was obtained because at a $\mathrm{pH}$ above $5.5, \mathrm{Al}^{3+}$ precipitates in the form of hydroxide $\left(\mathrm{Al}(\mathrm{OH})_{3} \cdot \mathrm{nH}_{2} \mathrm{O}\right)$. Similar results were observed by Medeiros et al. (2009) and Pértile et al. (2012).

The $\mathrm{Na}^{+}$contents increased linearly with increasing doses of the effluent at all depths, except at $0.6-0.8 \mathrm{~m}$ (Figure 1D); the highest increases were in the surface layers. The increase of $\mathrm{Na}^{+}$per cubic meter of effluent applied was $0.088 ; 0.144 ; 0.023$ and $0.007 \mathrm{mg} \mathrm{dm}^{-3}$ for the $0-0.2,0.2-0.4,0.4-0.6$ and 0.8-1.0 m depths, respectively. The largest absolute increase of $\mathrm{Na}^{+}$in the soil was observed at $0-0.2 \mathrm{~m}$; however, the greatest increase in $\mathrm{Na}^{+}$per effluent unit applied was observed at the 0.2-0.4 $\mathrm{m}$ depth.

So far, interpretation tables of $\mathrm{Na}^{+}$content in soil are expressed only as exchangeable sodium percentage (ESP), given by the equation proposed by Richards (1954): $\mathrm{ESP}=[\mathrm{In} /(\mathrm{Ca}+\mathrm{Mg}+\mathrm{K}+\mathrm{Na}$ $+\mathrm{Al}+\mathrm{M})] \mathrm{x} 100$. Thus, according to the percentage of $\mathrm{Na}^{+}$, soils are classified according to their sodicity. Given the highest $\mathrm{Na}^{+}$content observed, the ESP value was $3 \%$. Therefore, all soil samples within the columns are classified as non-sodium. The emergence and early growth of plants can be severely affected by sodicity, especially sensitive crops such as corn and soybeans (BLANCO et al., 2007). 
The Ca, Mg, K levels and Ca:Mg ratio

$\mathrm{Ca}^{2+}$ levels decreased at the 0-0.2 and 0.2-0.4 m depths with increasing effluent doses (Figure 2A). One of the possible explanations for this decrease might be the absence of $\mathrm{Ca}^{2+}$ in the effluent. In addition, there is a balance between cations, generating competition for the same site of ion exchange in the process of adsorption between $\mathrm{Ca}^{2+}$, $\mathrm{Mg}^{2+}$, and $\mathrm{K}^{+}$(PÉRTILE et al., 2012).

Figure 2. Exchangeable $\mathrm{Ca}, \mathrm{Mg}, \mathrm{K}$ levels and $\mathrm{Ca}: \mathrm{Mg}$ ratio at different depths of a Dystroferric Red Latosol (Oxisol) with different doses of the pharmaceutical industry effluent.
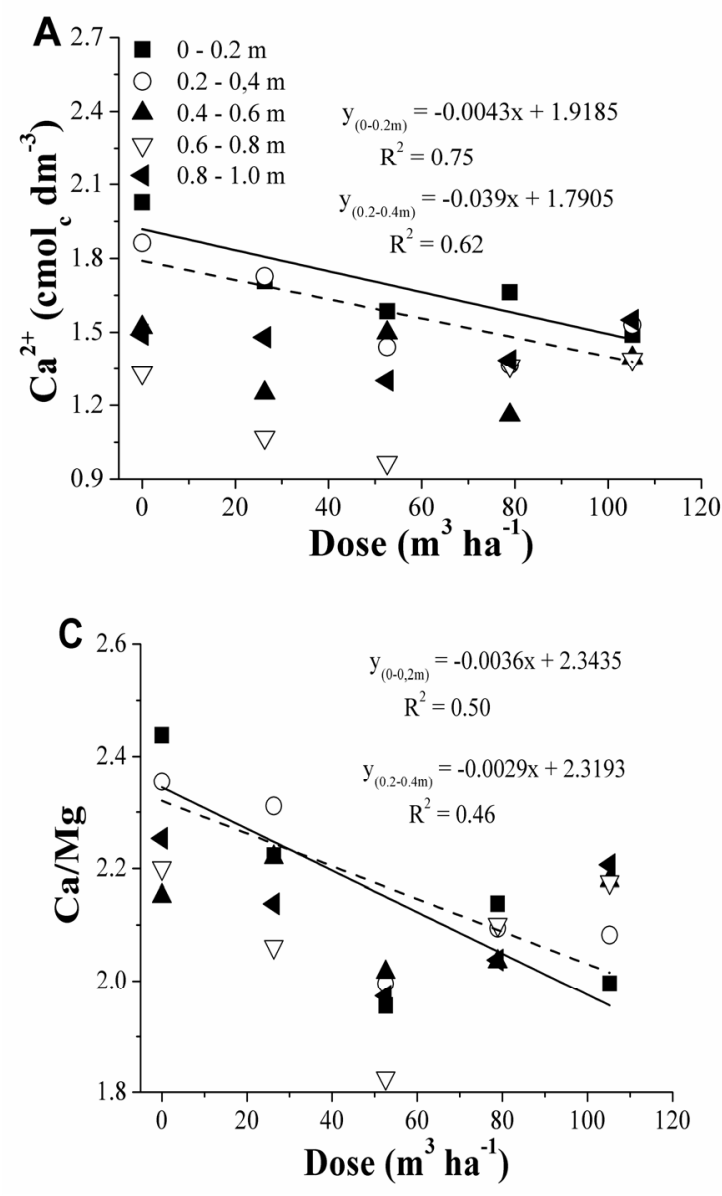

Maggi et al. (2011), working with swine wastewater and measuring leaching of soil nutrients, also found a decrease in the amount of $\mathrm{Ca}^{2+}$. They observed that $\mathrm{Ca}^{2+}$ concentration in the leachate increases with the rate of application of wastewater, demonstrating that the organic waste can increase the loss of this element, providing increased liberation of $\mathrm{CO}_{2}$ and consequently resulting in the leaching of $\mathrm{Ca}$ as $\mathrm{Ca}\left(\mathrm{HCO}_{3}\right)_{2}$. In regards to $\mathrm{Mg}^{2+}$ levels, there was no significant difference $(p>0.05)$
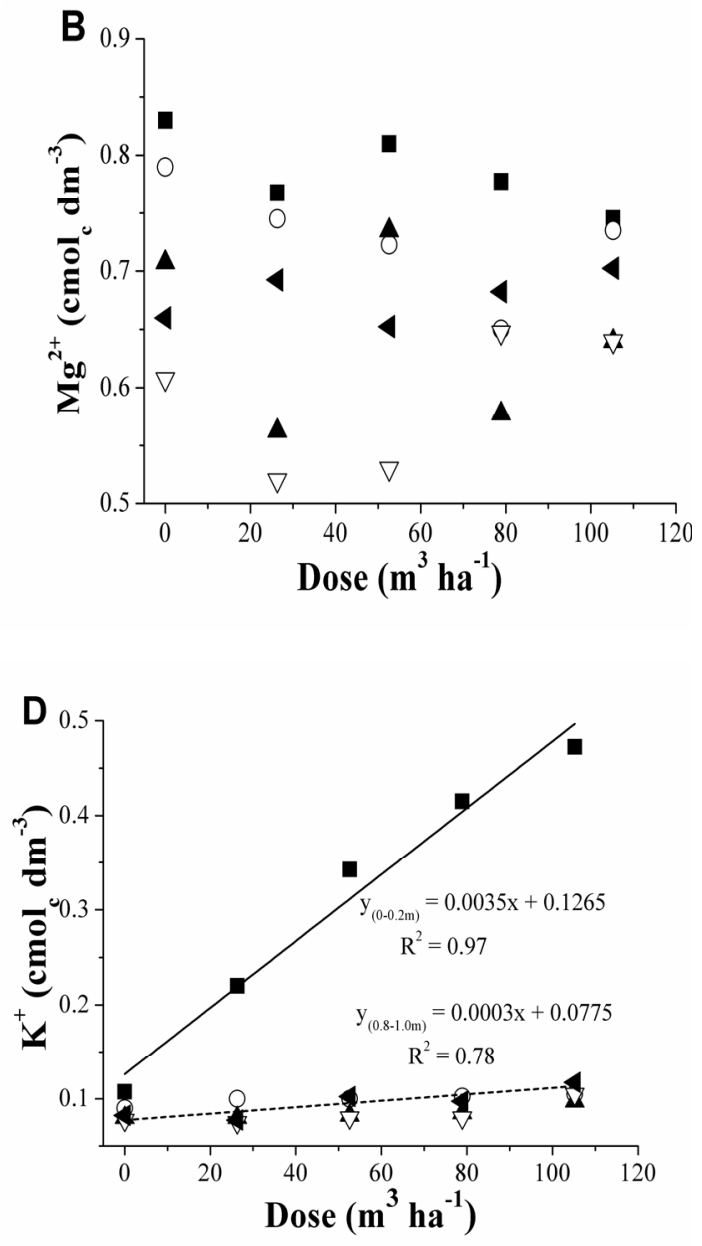

among doses applied in the experiment (Figure 2B). This result can also be explained by the low amount of $\mathrm{Mg}^{2+}$ in the effluent. Medeiros et al. (2009) also observed similar behavior of this cation.

The Ca:Mg ratio decreased significantly $(\mathrm{p}<$ 0.05 ) in the 0-0.2 and 0.2-0.4 m layers (Figure 2C). The optimal $\mathrm{Ca}: \mathrm{Mg}$ ratio may be variable according to the crops. Bueno et al. (2011) mentioned that the ideal ratio may range, but generally, the authors consider a $\mathrm{Ca}: \mathrm{Mg}$ ratio in the range of $3: 1$ or $4: 1$ 
to be optimal because these ratios are found in most naturally highly fertile soils. Thus, significant changes, like those observed in this research, may compromise the nutrient balance of the soil and consequently hinder plant development.

Medeiros et al. (2008) observed that high concentrations of exchangeable $\mathrm{Ca}^{2+}$ in the soil caused by the addition of lime with a high $\mathrm{Ca}: \mathrm{Mg}$ ratio inhibited the uptake of $\mathrm{K}^{+}$and $\mathrm{Mg}^{2+}$ by maize plants. The same authors reported that increased $\mathrm{Ca}: \mathrm{Mg}$ ratios in the soil decreased dry matter production and plant height in the early stages of development.

$\mathrm{K}^{+}$levels changed significantly $(\mathrm{p}<0.05)$ at the 0-0.2 and 0.8-1.0 $\mathrm{m}$ depths (Figure 2D). On the surface, the $\mathrm{K}^{+}$increase was larger for the applied effluent unit when compared to the deepest layer, 0.0035 and $0.0003 \mathrm{cmol}_{\mathrm{c}} \mathrm{dm}^{-3}$, respectively. This significant increase $(p<0.05)$ is likely due to the $\mathrm{K}^{+}$content in the effluent (Table 2). Furthermore, vertical $\mathrm{K}^{+}$mobility is influenced by the liquid that percolates into the soil column (MAGGI et al., 2011). The high $\mathrm{K}^{+}$concentrations in the effluent likely decreased $\mathrm{Ca}^{2+}$ and $\mathrm{Mg}^{2+}$ adsorption because it favors cation exchange processes in the soil (SILVA et al., 2011a). This may explain the decrease in the $\mathrm{Ca}^{2+}$ contents of the soils in this research.

\section{The $P$ and C levels}

$\mathrm{P}$ concentrations increased with the doses of effluent applied at a 0-0.2 $\mathrm{m}$ depth (Figure 3A). With the dose of $78.9 \mathrm{~m}^{3} \mathrm{ha}^{-1}$, $\mathrm{P}$ content reached $14.78 \mathrm{mg} \mathrm{dm}^{-3}$ as a result of the content of P present in the effluent. In the lower layers there were no significant differences $(p>0.05)$; this is likely due to the characteristic of phosphate ions, which have a high affinity for the clay mineral fraction, particularly iron and aluminum oxides; this means that $\mathrm{P}$ becomes adsorbed on the soil and thus has low mobility (CESSA et al., 2010).

According to EMBRAPA (2011), P contents in the $0-0.2 \mathrm{~m}$ depth ranged from average $(3.79 \mathrm{mg}$ $\left.\mathrm{dm}^{-3}\right)$ to high levels $\left(14.78 \mathrm{mg} \mathrm{dm}^{-3}\right)$ for soybean production. For example, for each cubic meter of effluent applied, there is an increase of $0.094 \mathrm{mg} \mathrm{dm}^{-}$ ${ }^{3}$. Ribeirinho et al. (2012) worked with application of sewage sludge and evaluated soil fertility; here, the authors obtained increment results of $\mathrm{P}$ content and concluded that alternative sources of $\mathrm{P}$ can be used to increase this soil nutrient because the sources of this element in nature are finite, and their rational use should be recommended (FIXEN, 2009).

There was no significant change in relation to $\mathrm{C}$ contents, although the effluent had levels of $1.56 \%$ $\mathrm{C}$ and $2.81 \%$ organic matter (Figure $3 \mathrm{~B}$ ).

Figure 3. The P and C levels at different depths of a Dystroferric Red Latosol (Oxisol) with different doses of the pharmaceutical industry effluent applied.
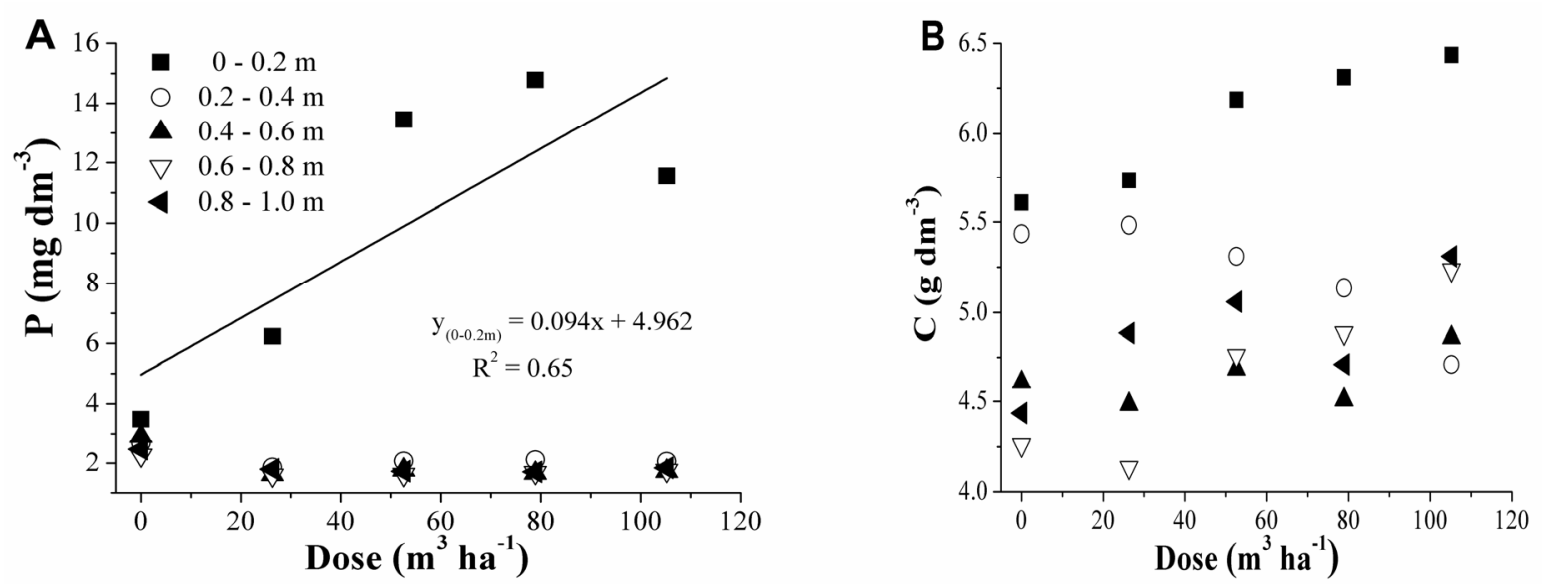


\section{The $\mathrm{Fe}, \mathrm{Cu}, \mathrm{Zn}$ and $\mathrm{Mn}$ contents}

There were no changes in the $\mathrm{Fe}^{3+}$ content of the soil (Figure 4A) after the application of different doses of effluent. This was due to the high iron oxides present in this soil class (COSTA et al., 1999). As can be observed in the third categorical level of the soil class used in this experiment (Dystrophic Red Latosol), the ferric character indicates $\mathrm{Fe}_{2} \mathrm{O}_{3}$ contents between 18 and 36\% (EMBRAPA, 2013). Obviously, the iron content measured in soil testing is not $\mathrm{Fe}^{3+}$, but because of the acidic nature of the extraction solution (Mehlich-1), this measurement may not be efficient and may overestimate iron $\left(\mathrm{Fe}^{2+}\right)$ content (SILVA et al., 2004).

$\mathrm{Cu}^{2+}$ levels increased with applied effluent doses in the 0-0.2 and 0.8-1.0 m depths, and the highest values were observed in the surface layer (Figure 4B). The initial content of this element in the soils was already considered high (more than $2 \mathrm{mg} \mathrm{dm}^{-3}$ ), and with the application of the effluent, it reached a maximum value of $27 \%$ and $9.53 \mathrm{mg} \mathrm{dm}^{-3}$ in the 0-0.2 m layer.

Figure 4. The $\mathrm{Fe}, \mathrm{Cu}, \mathrm{Zn}$ and $\mathrm{Mn}$ contents at different depths of a Dystroferric Red Latosol (Oxisol) with different doses of the pharmaceutical industry effluent.
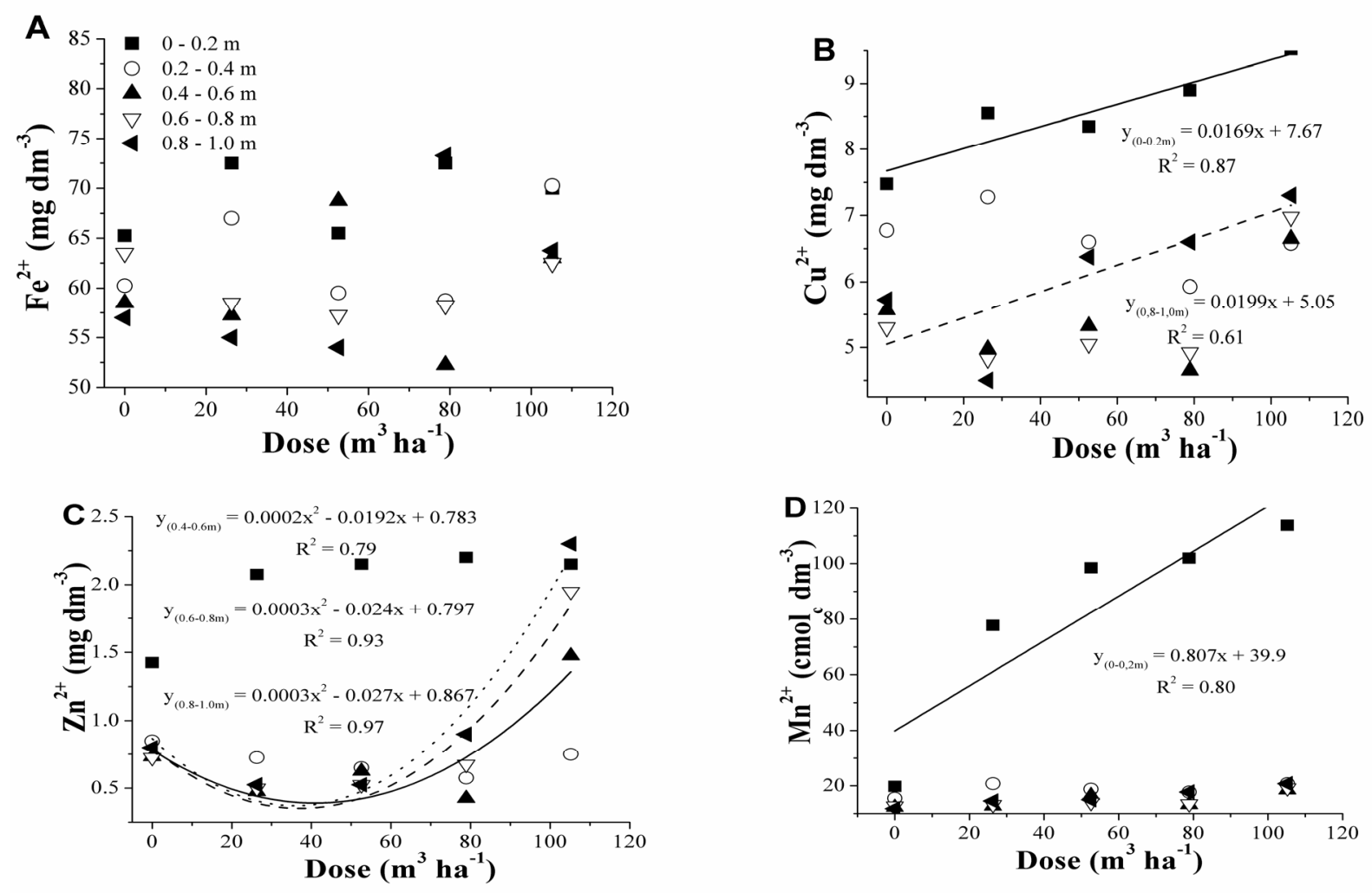

The increase of $\mathrm{Cu}^{2+}$ with depth $(0.8-1.0 \mathrm{~m})$ may have occurred as a result of preferential paths followed by the element in the soil column (SMANHOTTO et al., 2010). This is due to the affinity of $\mathrm{Cu}^{2+}$ for soluble organic compounds, which may increase mobility. The mobility of $\mathrm{Cu}^{2+}$ in the soil columns may also present a potential hazard and lead to the contamination of soil and ground water if the levels are very high.

In regards to $\mathrm{Zn}^{2+}$ levels, there was an increase in the 0.4-0.6, 0.6-0.8 and 0.8-1.0 m depths with increasing doses of effluent applied (Figure 4C). When $\mathrm{Zn}^{2+}$ is in the soil at high concentrations (i.e., more than $400 \mathrm{mg} \mathrm{dm}^{-3}$ ), it may cause toxicity symptoms in plants similar to $\mathrm{Fe}^{2+}$ and impair plant growth (TITO et al., 2011). Furthermore, $\mathrm{Zn}^{2+}$ is considered a relatively mobile element in soil (SMANHOTTO et al., 2010), and this might explain the increasing concentration with depth. 
$\mathrm{Mn}^{2+}$ levels increased significantly $(\mathrm{p}<0.05)$ with increasing effluent doses applied in the 0-0.2 m layer (Figure 4D). $\mathrm{Mn}^{2+}$ content reached $113.75 \mathrm{mg}$ $\mathrm{dm}^{-3}$ with the application of $105.2 \mathrm{~m}^{3} \mathrm{ha}^{-1}$ of effluent. Rosolem et al. (1992) showed that the toxicity symptoms due to $\mathrm{Mn}^{+2}$ were not observed even at high doses $\left(120 \mathrm{mg} \mathrm{dm}^{-3}\right)$ in limed soils conditions.

The $\mathrm{Mn}^{2+}$ ion has low mobility in soil, and this explain why the levels did not change according to the depth. This micronutrient, unlike aluminum, is very important to plant development. Its deficiency reduces plant growth, and excess of this element in the soil may cause toxicity to plants by inhibiting absorption of $\mathrm{Fe}^{2+}$ and $\mathrm{Zn}^{2+}$ (SILVA et al., 2011b).

\section{Conclusions}

The application of the alkaline effluent improved soil chemical attributes, particularly increasing $\mathrm{pH}$ values; $\mathrm{P}, \mathrm{K}^{+}, \mathrm{Cu}^{2+}, \mathrm{Mn}^{2+}$, and $\mathrm{Zn}^{2+}$ contents and decreasing the levels of $\mathrm{H}^{+}$.

$\mathrm{Mg}^{2+}, \mathrm{Al}^{3+}$ and $\mathrm{Fe}^{2+}$ levels were not influenced significantly by the application of the effluent.

The $\mathrm{pH}$ values as well as $\mathrm{P}, \mathrm{K}^{+}$and $\mathrm{Mn}^{2+}$ contents increased in the surface layers. $\mathrm{K}^{+}, \mathrm{Na}^{+}, \mathrm{Cu}^{2+}$ and $\mathrm{Zn}^{2+}$ contents increased in depth.

The $\mathrm{Ca}: \mathrm{Mg}$ ratio decreased with increasing doses of the effluent.

The $\mathrm{Na}^{+}$contents increased in all segments but did not reach levels considered to be harmful to the growth and development of plants.

The use of alkaline effluent in agricultural systems is an interesting alternative destination from socio-economic and agricultural perspectives.

\section{References}

ALBUQUERQUE, J. A.; MEDEIROS; J. C.; COSTA, A. D.; RENGEL, M. Aplicação de resíduo alcalino na superfície de Cambissolos. Bragantia, Campinas, v. 70, n. 4, p. 888-898, 2011.

ALMEIDA, H. C.; ERNANI, P. R.; ALBUQUERQUE, J. A.; MACABÔ JÚNIOR, J.; ALMEIDA, D. Influência da adição de um resíduo alcalino da indústria de papel e celulose na lixiviação de cátions em um solo ácido. Revista Brasileira de Ciência do Solo, Viçosa, MG, v. 32, n. 4, p. 1775-1784, 2008.

BLANCO, F. F.; FOLEGATTI, M. V.; GHEYI, H. R.; FERNANDES, P. D. Emergence and growth of corn and soybean under saline stress. Scientia Agricola, Piracicaba, v. 64, n. 5, p. 451-459, 2007.

BUENO, J. R. P.; BERTON, R. S.; SILVEIRA, A. P. D.; CHIBA, M. K.; ANDRADE, C. A.; MARIA, I. C. de. Chemical and microbiological attributes of an Oxisol treated with successive applications of sewage sludge. Revista Brasileira de Ciência do Solo, Viçosa, MG, v. 35, n. 4, p. 1416-1470, 2011.

CESSA, R. M. A.; VITORINO; A. C. T.; CELI, L.; NOVELINO, J. O.; BARBERIS, E. Adsorção de fósforo em frações argila na presença de ácido fúlvico. Revista Brasileira de Ciência do Solo, Viçosa, MG, v. 34, n. 5, p. 1535-1542, 2010.

COSTA, A. C. S.; BIGHAM, J. M.; RHOTON, F. E.; TRAINA, S. J. Quantification and characterization of maghemite in soils derived from volcanic rocks in Southern Brazil. Clays and Clays Minerals, Urbana, v. 47, n. 4, p. 466-473, 1999.

CRESTANA, G. B.; SILVA, J. H. Fármacos residuais: panorama de um cenário negligenciado. Revista Internacional de Direito e Cidadania, São Paulo, v. 9, n. 9, p. 55-65, 2011.

EMPRESA BRASILEIRA DE PESQUISA AGROPECUÁRIA - EMBRAPA. Manual de métodos de análises de solo. 2. ed. Rio de Janeiro: Embrapa, 1997. $212 \mathrm{p}$.

Sistema brasileiro de classificação de solos. Rio de Janeiro: Embrapa, 2013. 197 p.

. Tecnologias de produção de soja - região central do Brasil 2012 e 2013. Londrina: Embrapa, 2011. 261 p.

FIXEN, P. E. Reservas mundiais de nutrientes dos fertilizantes. In: PROCHNOW, L. I. (Ed.). Informações agronômicas, 126. Piracicaba: International Plant Nutrition Institute, IPNI, jun. 2009. p. 8-14.

GREGORY, P. J. Crescimiento y funcionamiento de las raíces. In: WILD, A. Condiciones del suelo y desarrollo de las plantas según Russel. Madrid: Mundi-Prensa, 1992. p. 121-175.

KROB, A. D.; MORAES, S. P.; SELBACH, P. A.; BENTO, F. M.; CAMARGO, F. A. O. Propriedades químicas de um Argissolo tratado sucessivamente com composto de lixo urbano. Ciência Rural, Santa Maria v. 41, n. 3, p. 433-439, 2011.

MAGGI, C. F.; FREITAS, P. S. L.; SAMPAIO, S. C. E.; DIETER, J. Lixiviação de nutrientes em solo cultivado com aplicação de água residuária de suinocultura. 
Revista Brasileira de Engenharia Agrícola e Ambiental, Campina Grande, v. 15, n. 2, p. 170-177, 2011.

MANTOVANI, J. R.; FERREIRA, M. E.; CRUZ, M. C. P.; BARBOSA, J. C. Alterações nos atributos de fertilidade em solo adubado com composto de lixo urbano. Revista Brasileira de Ciência do Solo, Viçosa, MG, v. 29, n. 5, p. 817-824, 2005.

MEDEIROS, J. C.; ALBUQUERQUE, J. A.; MAFRA, A. L.; BATISTELLA, F.; GRAH, J. Calagem superficial com resíduo alcalino da indústria de papel e celulose em um solo altamente tamponado. Revista Brasileira de Ciência do Solo, Viçosa, MG, v. 33, n. 6, p. 1657-1665, 2009.

MEDEIROS, J. C.; ALBUQUERQUE, J. A.; MAFRA, A. L.; DALlA ROSA, J.; PHILLIPPI, T. Resíduo alcalino da indústria de celulose na correção da acidez de um Cambissolo Húmico alumínico. Revista de Ciências Agroveterinárias, Lages, v. 12, n. 1, p. 78-87, 2013.

MEDEIROS, J. C.; MAFRA, A. L.; ALBUQUERQUE, J. A.; ROSA, J. D.; GATIBONI, L. C. Relação cálcio: magnésio do corretivo da acidez do solo na nutrição e no desenvolvimento inicial de plantas de milho em um Cambissolo Húmico álico. Semina: Ciências Agrárias, Londrina, v. 29, n. 4, p. 799-806, 2008.

MOREIRA, F. M. S.; SIQUEIRA, J. O. Soil microbiology and biochemistry, Lavras: UFLA, 2006. $626 \mathrm{p}$.

NASCIMENTO, E. P. Trajetória da sustentabilidade: do ambiental ao social, do social ao econômico. Estudos Avançados, São Paulo, v. 26, n. 74, p. 51-64, 2012.

PÉRTILE, P.; ALBUQUERQUE, J. A.; GABOTINI, L. C.; COSTA, A.; WARMLING, M. A. Application of alkaline waste from pulp industry to acid soil with pine. Revista Brasileira de Ciência do Solo, Viçosa, v. 36, n. 3, p. 939-950, 2012.

RIBEIRINHO, V. S.; MELO, W. J.; SILVA, D. H.; FIGUEIREDO, L. A.; MELO, G. M. P. Fertilidade do solo, estado nutricional e produtividade de girassol, em função da aplicação de lodo de esgoto. Pesquisa Agropecuária Tropical, Goiânia, v. 42, n. 2, p. 166-173, 2012.

RICHARDS, L. A. Diagnosis and improvement of saline and alkali soils. Washington: US Department of Agriculture, USDA Agricultural Handbook, 60, 1954. $160 \mathrm{p}$.

ROSOLEM, C. A.; BESSA, M. A.; AMARAL, P. G.; PEREIRA, H. F. M. Manganês no solo, sua avaliação e toxidez de manganês em soja. Pesquisa Agropecuária Brasileira, Brasília, v. 27, n. 2, p. 277-285, 1992.
SILVA, D. F.; MATOS, A. T.; PEREIRA, O. G.; CECON, P. R.; BATISTA, R. O.; MOREIRA, D. A. Alteração química de solo cultivado com capim Tifton 85 (Cynodon spp.) e fertirrigado com percolado de resíduo sólido urbano. Acta Scientiarum Tecnology, Maringá, v. 33, n. 3, p. 243-251, 2011 b.

SILVA, D. F.; MATOS, A. T.; PEREIRA, O. G.; CECON, P. R.; MOREIRA, D. A. Disponibilidade de sódio em solo com capim tifton e aplicação de percolado de resíduo sólido. Revista Brasileira de Engenharia Agrícola e Ambiental, Campina Grande, v. 14, n. 10, p. 1094-1100, 2010.

SILVA, G. B.; ROLIM, M. M.; PEDROSA, E. M. R.; BEBÉ, F. V.; SILVA, E. F. F. Efeito da aplicação de água residuária da lavagem dos frutos de café sobre as propriedades químicas do solo. Engenharia Agrícola, Jaboticabal, v. 31, n. 1, p. 158-166, 2011a.

SILVA, M. A. G.; MUNIZ, A. S.; COSTA, A. C. S.; CEGANA, A. C. V. Extratores para a quantificação de Fe em solos cultivados com soja. Acta Scientiarum Agronomy, Maringá, v. 26, n. 3, p. 367-372, 2004.

SMANHOTTO, A.; SOUSA, A. P.; SAMPAIO, S. S.; NÓBREGA, L. H. P.; PRIOR, P. Cobre e zinco no material percolado e no solo com a aplicação de água residuária de suinocultura em solo cultivado com soja. Engenharia Agrícola, Jaboticabal, v. 30, n. 2, p. 347-357, 2010.

SORATTO, R. P.; CRUSCIOL, C. A. C. Dolomite and phosphogypsum surface application effects on annual crops nutrition and yield. Agronomy Journal, Madison, v. 100, n. 2, p. 261-270, 2008.

TITO, G. A.; CHAVES, L. H. G.; GUERRA, H. O. C.; SOARES, F. A. L. Uso de bentonita na remediação de solos contaminados com zinco: efeito na produção de feijão. Revista Brasileira Engenharia Agrícola e Ambiental, Campina Grande, v. 15, n. 9, p. 917-923, 2011.

YUNES, R. A.; PEDROSA, R. C.; CECHINEL FILHO, V. Fármacos e fitoterápicos: a necessidade do desenvolvimento da indústria de fitoterápicos e fitofármacos no Brasil. Química Nova, São Paulo, v. 24, n. 1, p. 147-152, 2001.

ZIMMERMANN, F. J. P. Estatística aplicada à pesquisa agrícola. 2. ed. Brasília: Embrapa, 2014. 582 p. 